\title{
Extreme rainfall estimation on Bia watershed River in south-eastern of Côte d'Ivoire: theoretical and practical approaches application
}

\author{
KOUASSI Kan Martin, YAO Koffi Blaise, MELEDJE N'diaye Hermann, KOUASSI Kouakou \\ Lazare, SORO Nagnin and BIEMI Jean
}

\begin{abstract}
This study objective is to evaluate Gumbel's law exclusive use relative error of the in favor of theoretical and practical laws in extreme rainfall quantile estimation. To do this, an extreme rainfall database from 1941 to 2000 from the Bianouan, Agnibilékro, Adiaké and Ayamé rainfall stations on the Bia River watershed was established. The results analyzes show that the Fréchet and normal Log 2 laws are respectively the ideal laws of the theoretical and practical approach. In addition, a Gumbel's law exclusive use underestimates extreme rainfall quantiles compared to two approaches. Thus, Gumbel's law use could be justified by an economic or operational issue insofar as it understates the structures while minimizing the cost.
\end{abstract}

Index Terms - estimation errors - evaluation criteria Extreme rain - frequency model

\section{INTRODUCTION}

The phenomena related to rain and runoff have taken an appearance of natural disasters in many parts of the world. These phenomena occur with great intensity and their impacts are more and more considerable. From 1970 to 2012 in Africa, 1319 disasters caused 698,380 victims and financial losses of $\$ 26.6$ billion [1]. The Bia river watershed in the south-east of Côte d'Ivoire, which is the subject of this study, does not escape the phenomenon's. This basin hosts the Ayamé 1 and 2 hydroelectric dams. Managers do not find a plausible interpretation of recent events related to rainfall and runoff that have affected the hydrological functioning of these dams. In this context, frequency analysis can be an interesting approach. Indeed, this approach allows to attribute to an event, an order of magnitude to appreciate the abnormal or very abnormal, exceptional or very exceptional character [2], [3]. However, the ideal law choosing problem to attribute an order of magnitude to an extreme event leads Gumbel's law

KOUASSI Kan Martin, UFR-Science de la Terre et des Ressources Minières, Université Félix Houphouët Boigny, Centre de Recherche en Ecologie, Abidjan, Cote d'Ivoire, +225 48052479

YAO Koffi Blaise, UFR-Science de la Terre et des Ressources Minières, Université Félix Houphouët Boigny, Abidjan, Cote d'Ivoire, +225 082062 31

MELEDJE N'diaye Hermann, Centre de Recherche en Ecologie, Université Nangui Abrogoua, Abidjan, Côte d'Ivoire, +225 57431520 ,

KOUASSI Kouakou Lazare, Université Lorougnon Guédé, Daloa Côte d'Ivoire, Centre de Recherche en Ecologie, Université Nangui Abrogoua, Abidjan Côte d'Ivoire, +22509560570

SORO Nagnin, UFR-Science de la Terre et des Ressources Minières, Université Félix Houphouët Boigny, Abidjan, Cote d'Ivoire, +225 224830 03

BIEMI Jean UFR-Science de la Terre et des Ressources Minières, Université Félix Houphouët Boigny, Abidjan, Cote d'Ivoire, +225 069938 91 exclusive use. The popularity of this law is linked to the simplicity of the calculation of its distribution and to the geometric configuration of the linear probability scale. Although this approach is a very operational concern, we can wonder about the differences obtained with the appropriate law. These differences could impact the level of safety and cost of civil engineering works. This is the object of this study. It evaluates the relative error of Gumbel's law exclusive using compared to the theoretical and practical laws in maximum daily rainfall quantiles estimate on the Bia River watershed.

\section{STUDY AREA PRESENTATION}

Bia is a transboundary river between Côte d'Ivoire and Ghana; it flows between latitude $5^{\circ} 30$ 'and $5^{\circ} 50^{\prime}$ north and between longitude $3^{\circ}$ and $3^{\circ} 15^{\prime}$ 'west (Fig. 1). Its source is in Kérimasso in northern Ghana and flows into the Aby lagoon in southern Côte d'Ivoire [4].The catchment area of the Bia is elongated and covers an area of $9650 \mathrm{~km}^{2}$ of which $2 / 3$ are located in the Ghanaian territory. The rainfall analysis done by [5], makes it possible to distinguish two (2) climatic zones on the basin of the Bia. A humid tropical zone $(1,460 \mathrm{~mm})$ corresponding to the northern part of the basin with a single rainy season and a subequatorial zone $(1,870 \mathrm{~mm})$ corresponding to the south of the basin with two distinct rainy seasons.

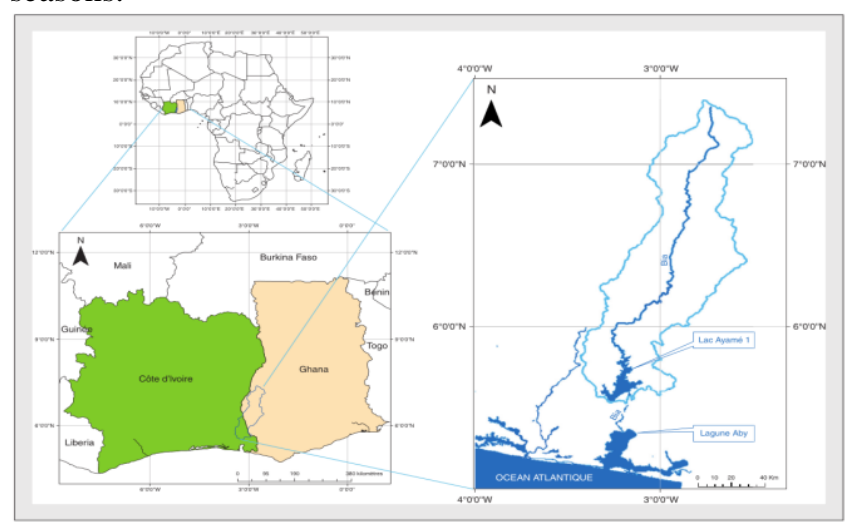

Figure 1 : Location of the study area [6]

\section{MATERIALS AND DATA}

The Bia basin maximum daily rainfall extracted from daily rainfall data from 1st January 1941 to 31 December 2000 at the Adiaké, Ayamé, Agnibilékro and Bianouan rain stations [7]. Table I summarizes the coordinates of the various stations. HYFRAN (Hydrological Frequency Analysis) software was used to estimate extreme rainfall quantiles at the different stations. 
Extreme rainfall estimation on Bia watershed River in south-eastern of Côte d'Ivoire: theoretical and practical approaches application

Table I : Rainfall stations localization

\begin{tabular}{|c|c|c|c|c|}
\hline $\begin{array}{c}\text { Rainfall } \\
\text { stations }\end{array}$ & Adiaké & Agnibilékro & Ayamé & Bianouan \\
\hline Latitude (DD) & 5.3 & 7.12 & 5.6 & 6.03 \\
\hline $\begin{array}{c}\text { Longitude } \\
\text { (DD) }\end{array}$ & $-3,3$ & -3.2 & 3.17 & 3.2 \\
\hline
\end{tabular}

\section{METHODOLOGY}

\section{A. Extreme rainfall quantiles estimation}

The ideal law choice for extremes daily rainfall quantiles estimating should be guided by theoretical and practical considerations to avoid under or overestimation.

In the theoretical approach, the maximum daily rainfall of each station is adjusted to the Generalized Law of Extreme Values (GEV) with three (3) components; Gumbel (1), Weibull (2) and Fréchet (3). The GEV law form parameter (k) sign allows determined the ideal law. So, if $\mathrm{k}=0$; the rain follows the Gumbel law $(\mathrm{Gu})$, if $\mathrm{k}>0$; the rain is the Weibull law $(\mathrm{Wu})$ and if $\mathrm{k}<0$; the rain adjusts with the Fréchet law (Fre).

Gumbel law:

$$
f(x)=\frac{1}{\alpha}\left(1-\frac{x-u}{\alpha}\right)^{\frac{1}{\bar{k}}-1} \exp \left\{-\left[1-k\left(\frac{x-u}{\alpha}\right)\right]^{\frac{1}{k}}\right\}
$$

Frechet law:

$$
f(x)=\frac{1}{\alpha}\left(1-\frac{x-u}{\alpha}\right) \exp \left\{-\left[1-k\left(\frac{x-u}{\alpha}\right)\right]^{\frac{1}{k}}\right\}
$$

In the practical approach, no law is a priori ideal for estimating the quantiles of an extreme phenomenon. Thus, several laws are adjusted to the phenomenon and ideal law is chosen by means of evaluation criteria. In this study, we adjust the maximum daily rainfall from different stations at four (4) law. The three (3) laws that make up the GEV law and the normal Log 2 law (4).

Normal $\log 2$ :

$$
f(x)=\frac{1}{x \sigma \sqrt{2 \pi}} \exp \left\{-\frac{(\ln x-m u)^{2}}{2 \sigma^{2}}\right\}
$$

AIC (Akaike Information Criterion) criteria (5) and BIC (Bayesian Information Criterion) criteria (6) are used to choose the ideal law among the four laws used [8] [9]. The principle of these criteria is that the lower the values, the more the associated model is adapted to the adjustment of the variable concerned [10].

$$
A I C=-2 \ln (L)+2 k(5): B I C=-2 \ln (L)+2 k \ln (N)(6)
$$

$\mathrm{L}$ : the likelihood of the sample, $\mathrm{k}$ : the number of parameters and $\mathrm{N}$ : sample size

In addition, for the different approachs, the empirical frequency is estimated by the Cunane method [11] and [12] with relation (7). This empirical probability has the advantage of being less biased on extreme values [11]. The laws parameters are estimated by the maximum likelihood method because this method produces a low sampling variance of the

estimated parameters and therefore a small quantile variance [13] and [14].

$$
F_{i}=\frac{i-0,4}{N+0,2}
$$

$\mathrm{i}$ : number of the extreme variable and $\mathrm{N}$ : sample size

Quantiles are estimated for return periods of 6 to 100 years. This interval integrates [2] and [3]. Thus, for a very exceptional and exceptional rainfall the return period is respectively 100 and 30 years whereas for return periods of 30 and 10 years the rain is respectively very abnormal and abnormal.

\section{B. Estimation error}

The relative error between Gumbel law (operational approach) exclusive use in civil engineering works and theoretical and practical ideal laws is estimated through the relation (8).

$$
E R(T)=\left(\frac{Q_{G u}-Q_{T h \text { ouP }}}{Q_{\text {Th ouP }}}\right) \times 100
$$

$\mathrm{Q}_{\mathrm{Gu}}$ : quantile esteemed with Gumbel law; $\mathrm{Q}_{\mathrm{Th} \mathrm{ou} \mathrm{P}}$ : Quantile esteemed with theorical or practice law and $\mathrm{T}$ : return periods

\section{RESUltS}

\section{A. Theoretical approach}

Table II summarizes GEV law form parameter (k) values estimated with the maximum daily rainfall at the different stations

Table II : GEV law form parameter (k) values

\begin{tabular}{|c|c|c|c|c|}
\hline Parameters & Adiaké & Agnibilékro & Ayamé & Bianouan \\
\hline $\mathbf{k}$ & -0.07 & -0.02 & -0.15 & -0.10 \\
\hline
\end{tabular}

The table analysis shows that at all the stations, the value of $\mathrm{k}$ remains less than 0. Consequently, the Bia basin maximum daily rainfall from the four rainfall stations adjust at the Fréchet law.

The maximum rainfall quantiles estimated with the Fréchet law (theoretical law) are summarized in the figure for the different return periods according to a 95\% confidence interval. Fig. 2 analysis shows that the uncertainty about quantile estimation increases with the return period. These uncertainties are greater at the Bianouan station and lower at Agnibilékro

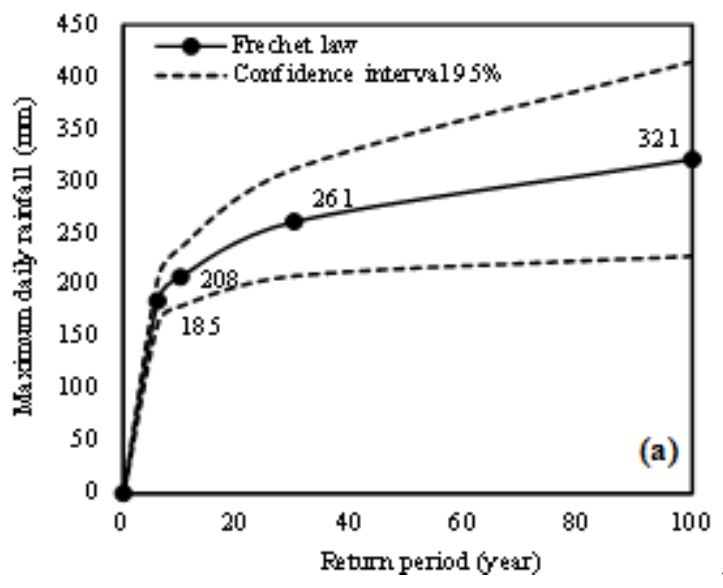



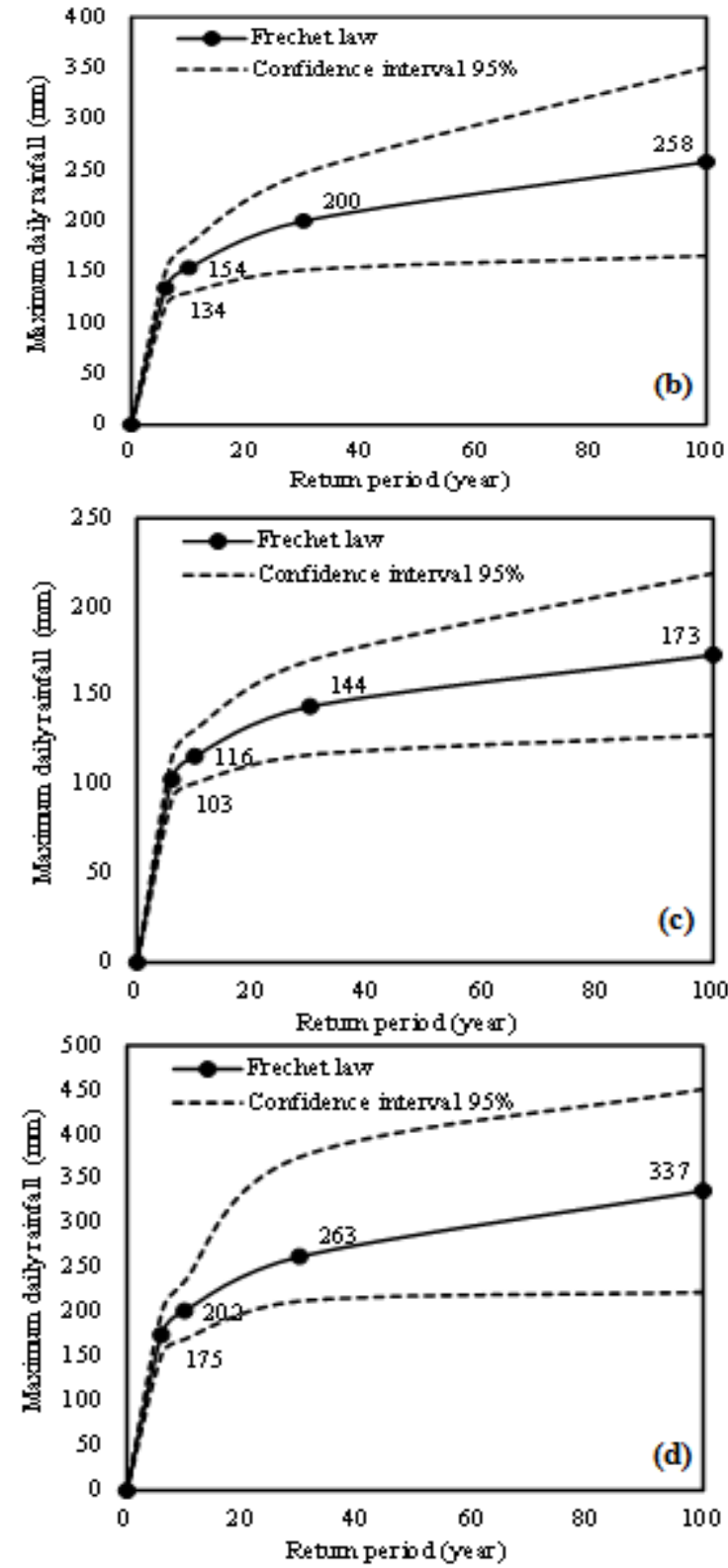

Figure 2: Maximum rainfall quantiles estimation with the theoretical law at a $95 \%$ confidence interval at the Adiaké (a), Ayamé (b), Agnibilékro (c) and Bianouan (d) pluviormetric stations

\section{B. Theoretical approach}

Table III summarizes the AIC and BIC criteria values associated with the different laws used in the practical approach for each station. The table observation reveals that the AIC and BIC values associated with the normal Log 2 law are the lowest at the four stations. This law is therefore the ideal law for extremes rainfall quantiles estimate at the studied stations.

Table III: Numeric evaluation criterion

\begin{tabular}{|c|c|c|c|c|}
\hline \multirow{2}{*}{ Stations } & \multirow{2}{*}{ Criterion } & \multicolumn{3}{|c|}{ Statistics laws } \\
\cline { 3 - 5 } & & GEV & Gu & LN2 \\
\hline \multirow{2}{*}{ Adiaké } & BIC & 642.86 & 639.19 & 638.89 \\
\cline { 2 - 5 } & AIC & 636.58 & 635 & 634.7 \\
\hline \multirow{2}{*}{ Ayamé } & BIC & 604.92 & 603.21 & 603.12 \\
\cline { 2 - 5 } & AIC & 598,64 & 599,93 & 598,93 \\
\hline \multirow{2}{*}{ Agnibilékro } & BIC & 578.31 & 574.28 & 574.08 \\
\cline { 2 - 5 } & AIC & 572.03 & 570.09 & 569.89 \\
\hline \multirow{2}{*}{ Bianouan } & BIC & 652.49 & 649.83 & 649.13 \\
\cline { 2 - 5 } & AIC & 646.2 & 645.64 & 644.95 \\
\hline
\end{tabular}

The fig. 3 shows the uncertainties on the estimation of maximum rainfall quantiles at the different stations with the normal Log 2 law (practical law).
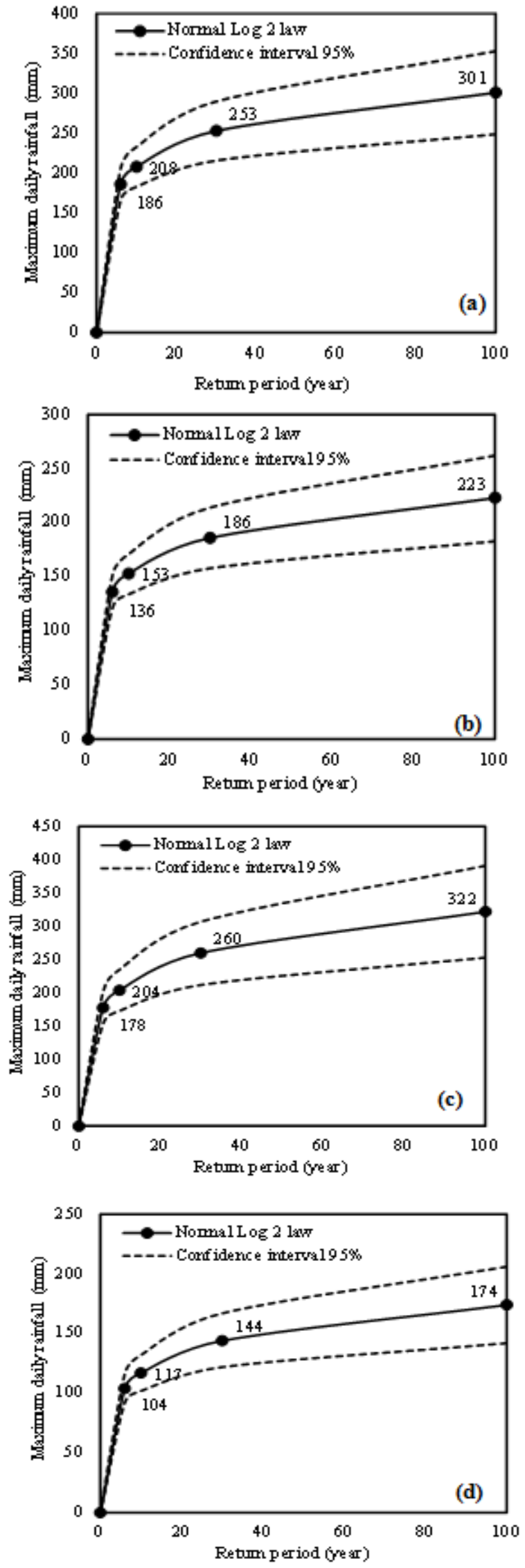

Figure 3: Maximum rainfall quantiles estimation with the practical law at a $95 \%$ confidence interval at the Adiaké (a), Ayamé (b), Agnibilékro (c) and Bianouan (d) pluviormetric stations 


\section{approaches application}

An evolution similar to the theoretical approach is observed. Indeed, the irregularity in the estimation of the quantiles of rain with the normal Log 2 law is greater in Bianouan and lower in Agnibilékro. Moreover, the synthesis of the two figures shows that the uncertainty associated with estimating maximum rainfall quantiles at the different stations is greater in the theoretical than in the practical approach.

\section{Relative error}

Table IV summarizes the relative errors between Gumbel's law and the theoretical law (Fréchet law) then the practical law (normal Log 2 law). The table analysis shows that for quantiles of maximum daily estimated rainfall the relative error remains below 0 at all stations. As a result, Gumbel's law underestimates all quantiles of rain in relation to two approaches.

Moreover, Gumbel and Fréchet laws coincide in the estimation of the very abnormal and abnormal rain at Agnibilékro. Too, these two laws coincide in the estimate of the abnormal rain in Bianouan. Moreover, relative error remain below $10 \%$ except those observed between the Gumbel and Fréchet laws in very exceptional rainfall estimation at Ayamé (-16.28\%) and Bianouan (-11.57\%) rain stations.

Table IV: Relative error between Gumbel law and LN2 (theoretical law) and Fre (the practical law

\begin{tabular}{|c|c|c|c|c|c|}
\hline \multirow{2}{*}{ Stations } & $\begin{array}{c}\text { relative error } \\
\text { between }\end{array}$ & $\begin{array}{c}\mathrm{T}=100 \\
\text { years }\end{array}$ & $\begin{array}{c}\mathrm{T}=30 \\
\text { years }\end{array}$ & $\begin{array}{c}\mathrm{T}=10 \\
\text { years }\end{array}$ & $\begin{array}{c}\mathrm{T}=6 \\
\text { years }\end{array}$ \\
\hline \multirow{3}{*}{ Adiaké } & Gu and LN2 & -0.66 & -0.79 & $-0,96$ & $-1,08$ \\
\cline { 2 - 6 } & Gu and Fre & -6.85 & -3.83 & $-0,96$ & $-0,54$ \\
\hline \multirow{3}{*}{ Agnibilékro } & Gu and LN2 & -1.72 & $-0,69$ & $-0,85$ & $-0,96$ \\
\cline { 2 - 6 } & Gu and Fre & -1.16 & $-0,69$ & 0,00 & 0,00 \\
\hline \multirow{3}{*}{ Ayamé } & Gu and LN2 & -3.14 & $-2,15$ & $-2,61$ & $-1,47$ \\
\cline { 2 - 6 } & Gu and Fre & -16.28 & $-9,00$ & $-3,25$ & 0,00 \\
\hline & Gu and LN2 & -7.45 & $-5,38$ & $-2,94$ & $-1,69$ \\
\cline { 2 - 6 } & Gu and Fre & -11.57 & $-6,46$ & $-1,98$ & 0,00 \\
\hline
\end{tabular}

\section{DISCUSSION}

The theoretical and practical considerations guided extreme rainfall quantiles estimation in this study. Thus according to the theoretical approach, the maximum daily rainfall of the four (4) stations of the Bia basin follows the Fréchet law insofar as the GEV law form parameter $\mathrm{k}$ remains below 0 at these stations. These observations reveal a recurrence of extreme precipitation over the Bia River watershed [15], [16]. This recurrence appears more intense in Ayamé than in Agnibilékro because the form parameter k of Fréchet's law is higher in absolute value in Ayamé (-0.15) than in Agnibilékro $(-0.02)$. This rainfall extremes distribution is similar to that observed by [17] on this same watershed. Extreme daily rainfall quantiles estimation in a practical context shows that the normal Log 2 (NL2) law more adequately estimates daily extreme rainfall from the four stations. These results point out that in terms of quantification of the risks associated with extreme daily rainfall in the Bia River watershed, the generalized law of type I extreme values (Gumbel law) should not be favored. Similar analyzes have been done in Côte d'Ivoire [18] and [19]. Indeed, [19] showed that the Gumbel model could not be used exclusively for quantifying the risk associated with extreme rainfall. Similarly, [18] reveals that out of 44 series of annual maxima studied, only $34 \%$ have an exponential asymptotic distribution (Gumbel's law). In North Africa, [20] made similar observations in Tunisia. [21] concludes in France that Gumbel's law does not predominate in the estimation of extreme rainfall. These results confirm some author's skepticism as to this law exclusive use in the extreme rain estimation in engineering [22], [23] and [24]. However, [25] emphasizes that Gumbel's law using amounts to giving maximum risk to engineering works by underestimating the quantiles. Similar observations have been made in this study. Indeed, Gumbel's law exclusive use in favor of the theoretical (Fréchet law) and practical (normal Log 2) laws shows that Gumbel's law underestimates the extreme rainfall quantiles compared to the two approaches at all stations. This observation has already been made by several studies [26], [27] and [28]. Thus, the Gumbel's law used in the extreme daily rainfall quantiles estimation in civil engineering projects on the Bia watershed would undersize structures while minimizing the cost and the security level. However, [29] recommends a tolerance of $10 \%$ for the calculation of such a severe quantile. In this study, the relative error in the practical context (NL2) is less than $10 \%$ at all stations therefore acceptable, contrary to the theoretical context (Fre) or the relative error exceeds $10 \%$ in the estimation of the very exceptional rainfall in Ayamé $(-16.28 \%)$ and Bianouan $(-11.57 \%)$. This difference can explain probably to the fact that the two-parameter normal log law belongs to Gumbel's attraction domain [18], [30] and [28].

\section{CONCLUSION}

This study allowed us to show that theoretically, the extremes rainfall daily on the Bia River watershed are adequate estimated with Frechet model while in a practical context, these rains are ideally estimated with the Lognormale law with two parameters. In addition, the operational context characterized by Gumbel's law exclusive use underestimates the maximum rainfall quantiles in compared to the practical law (NL2) and the theoretical law (Fre). The practical relative error $(-0.67 \%$ to $-8.05 \%)$ remain below $10 \%$ whereas theoretically (0 to $-16.28 \%$ ) the values exceed $10 \%$ in Ayamé and Bianouan in the very exceptional rain estimate.

\section{REFERENCES}

[1] OMM: Organisation météorologique Mondiale (2014) : Déclaration sur l'état du climat mondial, 1152 (2014), 24p.

[2] S. Sene et P. Ozer, Évolution pluviométrique et relation inondations événements pluvieux au Sénégal. Bulletin de la Société géographique de Liège 42 (2002), pp. 27-33

[3] B. Monhymont and G. R. Demarée. Courbes intensité-durée-fréquence des précipitations à Yangambi, Congo, au moyen de différents modèles de type Montana. Journal des Sciences Hydrologiques, 51 (2), 2006, pp. 239 - 253

[4] C. Reizer, Aménagement piscicole du lac artificiel d'Ayamé, CTFT 1967, 108p.

[5] N. E. H. Meledje, Modélisation de la dynamique hydrologique et du flux des sédiments dans le lac du barrage hydroélectrique d'Ayamé 1. Thèse unique de doctorat, Université Nangui Abrogoua, Côte d'Ivoire 2016, 197p 
[6] N. H. Meledje, K. L. Kouassi, Y. N. N'go et I. Savane, Caractérisation des occurrences de sécheresse dans le bassin hydrologique de la Bia transfrontalier entre la Côte d'Ivoire et le Ghana : contribution des chaînes de Markov. Cah Agric, 2015, 24(83), 12p.

[7] J F. Boyer, C. Dieulin, N. Rouche, A. Cres, E. Servat, J. E. Paturel et G. Mahé, SIEREM an environmental information system for water resources. 5th World FRIEND Conference, La Havana - Cuba, November 2006 in Climate Variability and Change - Hydrological Impacts IAHS Publ, 308 (2006), pp. 19-25.

[8] H. Akaike, A new look at the statistical model identifical. IEEE Transactions on Automatic Control 19, 1974, pp. 716 - 723.

[9] G. Schwartz, Estimating the dimension of a model. The Annals of statistics, 6 (1978), pp. $461-464$

[10]Rao and Hamed. Flood Frequency Analysis. CRC Press 2001, New York, United States, 350p

[11]S. Guo, A discussion on unbiased plotting positions for the extreme value distribution, Journal of Hydrology 121 (1-4), 1990, pp. 33 - 44.

[12]C. Cunnane, Unbiased plotting position. Journal of Hydrology, 37, 1978, pp. $205-222$

[13]J. Greenwood, J. Landwehr, N. Matalas et J. Wallis, Probability weighted moments: definition and relation to parameters of several distributions expressable in inverse form. Water Resources Research 15, 1979, pp. 1049 - 1054.

[14]P. Meylan, A. C. Favre et A. Musy, Hydrologie fréquentielle, une science prédictive. 1ere Edition. Presses Polytechniques et Universitaires Romandes, Lausanne, 2008, 174p.

[15]Pickands. Statistical inference using extreme order statistics. Annals of statistics 3 (1975), pp. 119-131.

[16]E. J. Gumbel, Statistics of Extremes. Columbia University Press, New York, United States, 1958, 375p.

[17]K. M. Kouassi, K. L. Kouassi, K. B. Yao, N. H. Meledje, J. Biemi, T. Lasm, and R. Nathalie Variabilité des extrêmes pluviométriques sur le bassin versant de la rivière Bia (Sud-Est, Cote d'Ivoire). European Scientific Journal 14(2), 2018, pp. 1857 - 7881.

[18]G. E. Soro, Modélisation statistique des pluies extrêmes en Côte d'Ivoire. Thèse de Doctorat Universtisé Nangui Abrogoua, Côte d'Ivoire, 2011, 192p.

[19]B. T. A. Goula, B. Konan, Y. T. Brou, I. Savané, V. Fadika et B. Srohourou, Estimation des pluies exceptionnelles journalières en zone tropicale: cas de la Côte d'Ivoire par comparaison des lois Lognormale et de Gumbel. J. des Sc. Hydrologiques 52 (2), 2007, pp. 4967.

[20]Z. Yadh, et J. P. Laborde, Modélisation statistique et synthèse cartographique des précipitations journalières extrêmes de Tunisie. Revue des sciences de l'eau, 20(4), 2007, pp. 409-424.

[21]A. Muller, Comportement asymptotique de la distribution des pluies extrêmes en France. Thèse de doctorat ès science, Université Montpellier II, France 2006, 246p.

[22]D. Koutsoyiannis, On the appropriateness of the Gumbel distribution for modelling extreme rainfall. In A. Brath, A. Montanari and Toth E. (Eds.): recent advances in peak river flow modelling, prediction and real-time forecasting. Assessment of the impacts of land-use and climate changes. Editoriale Bios, Castrolibero, Italy, 2004c, pp. 303 - 319.

[23]D. Ramon, C. Bouvier, N. Luc et N. Hélène, Approche régionale pour l'estimation des distributions ponctuelles des pluies journalières dans le Languedoc-Roussillon. Journal des Sciences Hydrologiques, 50 (1), 2005, pp. 17 - 29.

[24]Bacro et Chaouche, Incertitude d'estimation des pluies extrêmes du pourtour méditerranéen : illustration par des données de Marseille. Journal des Sciences Hydrologiques, 51 (3), 2006, pp. 389 - 405

[25]D. Koutsoyiannis, Statistics of estimation of extreme rainfall I. Theoretical of investigation. Hydrological Sciences Journal, 49 (4), 2004a, pp. 575 - 590 . 